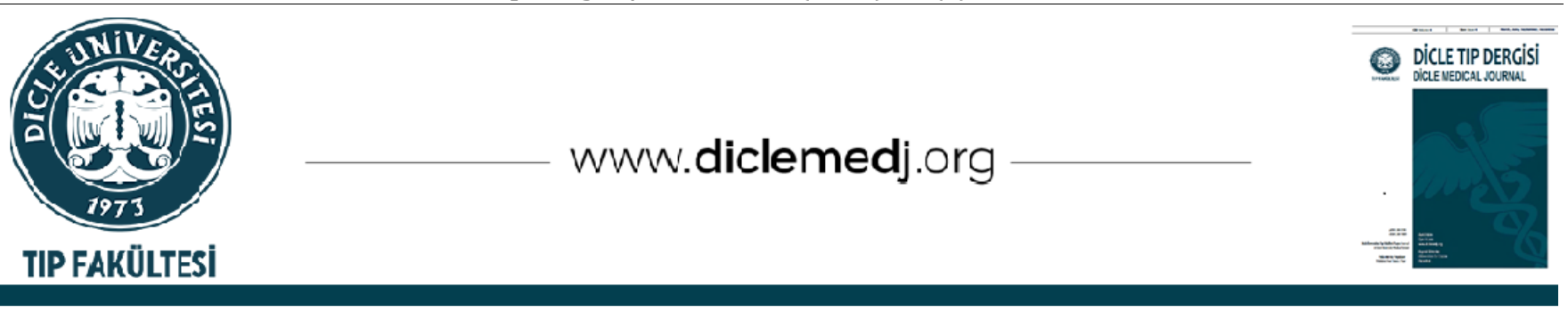

Original Article / Özgün Araştırma

\title{
Relationship Between Paraoxonase-1 Activity and Pulse Pressure Index in Patients with a Acute Ischemic Stroke
}

\author{
Unal Ozturk ${ }^{i}{ }_{1}$, Onder Ozturk ${ }^{2}$, Sebnem Nergiz ${ }^{i}{ }_{3}$, Yusuf Tamam ${ }_{4}$, Sefer Varol ${ }_{4}$ \\ 1 University of Health Sciences Turkey, Diyarbakır Gazi Yasargil Education and Research Hospital, Department of Neurology, Diyarbakir Turkey \\ 2 University of Health Sciences Turkey, Diyarbakır Gazi Yasargil Education and Research Hospital, Department of Cardiology, Diyarbakir Turkey \\ 3 Dicle University Medical Faculty, Department of Microbiology, Diyarbakir Turkey
}

4 Dicle University Medical Faculty, Department of Neurology, Diyarbakir Turkey

Received: 16.04.2020; Revised: 30.08.2020; Accepted: 31.08.2020

\begin{abstract}
Objectives: Stroke is a multifactorial disease. Oxidative stress and blood pressure were found to be closely related with cardiovascular and cerebrovascular diseases. Paraoxonase-1 (PON1) has been considered as an anti-atherosclerosis factor. Increased pulse pressure (PP) may lead to an increased risk of cardiovascular and cerebrovascular morbidity and mortality. Nevertheless, there are limitations for PP as an evaluation index. In order to overcome the defects of PP, there is a novel parameter, "pulse pressure/systolic pressure" called "pulse pressure index (PPI)" for evaluation of cardiovascular outcomes. We investigated the association between Paraoxonase1 (PON1) activities and pulse pressure index (PPI) in acute ischemic stroke patients.

Methods: We evaluated and compared the PON-1 activity and PPI in 46 ischemic stroke patients and 32 control patients. PON1 activitity was measured with UV spectrophotometric method by using "Rel Assay Diagnostic" kits. Pulse pressure was calculated by subtraction of diastolic blood pressure from systolic blood pressure. PPI was calculated "pulse pressure / systolic pressure".

Results: Hypertension, age, diabetes mellitus, dyslipidemia signficantly higher in ischemic stroke patients than control group ( $<<0.05$ ). PPI was significantly higher in ischemic stroke patients than control group $(0.471 \pm 0.072$ and $0.423 \pm 0.048$, p<0.05). PON-1 activity was significantly lower in ischemic stroke patients than in control group (417.76 \pm 79.72 and $432.34 \pm 92.05 p<0.05)$. We found that a weak negative correlation between the PPI and LVEF, PON1 $(\mathrm{p}<0.05)$. Also, PON1 is independent predictor of PPI.

Conclusion: This study demostrated that PON1 activity is lower and PPI is higher in acute ischemic stroke patients than control subjects. Our results suggested that, PON-1 activity is an independent predictor of PPI in acute ischemic stroke patients. PON-1 weakly correlates with pulse pressure index.
\end{abstract}

Keywords: Paraoxonase, pulse pressure, stroke.

\section{DOI: 10.5798/dicletip.850304}

Correspondence / Yazıșma Adresi: Onder Ozturk, University of Health Sciences Turkey, Diyarbakir Gazi Yasargil Education and Research Hospital Department of Cardiology, Uckuyular / Kayapinar, Diyarbakir, Turkey e-mail: droozturk21@hotmail.com 


\section{Akut İskemik İnmeli Hastalarda Paraoksonaz-1 Aktivitesi ile Nabız Basıncı İndeksi Arasındaki İlişsi}

Öz

Amaç: İnme multifaktöriyel bir hastalıktır. Oksidatif stres ve kan basıncının, kardiyovasküler ve serebrovasküler hastalıklar ile yakın ilişkili olduğu bulunmuştur. Paraoksonaz-1 (PON1) in antiaterosklerotik faktör olduğu düşünülmektedir. Artmış nabız basıncı (PP), artmış kardiyovasküler ve serebrovasküler morbidite ve mortalite ile ilişkilidir. Bununla beraber, PP'nin bir indeks olarak değerlendirilebilmesi için sınırlamalar vardır. PP'deki bu sınırlamaları ortadan kaldırmak ve kardiyovasküler prognozu değerlendirmek için yeni bir parametre "nabız basıncı/sistolik basınç" formülünden hesaplanarak nabız basıncı indeksi (PPI) bulunmuştur. Yapmış olduğumuz bu çalıșmada, akut iskemik inmeli hastalarda PON1 aktivitesi ile PPI arasındaki ilişkiyi araştırdık.

Yöntemler: Bu çalışmamızda 46 iskemik inmeli hasta ve 32 kontrol grubunda, PON-1 aktivitesi ile PPI değerlendirip karşılaştırdık. PON1 aktivitesi "Rel Assay Diagnostic" kit kullanılarak UV spektrofotometre ile ölçüldü. Nabız basıncı, sistolik kan basıncından diyastolik kan basınıcının çıkarılmasıyla ölçüldü. PPI, "nabız basıncı/sistolik basınç” formülünden hesaplandı.

Bulgular: Hipertansiyon, yaş, diyabetes mellitus, dislipidemi, kontrol grubuna göre iskemik inmeli hastalarda anlamlı düzeyde daha yüksek bulundu $(\mathrm{p}<0.05)$. PPI, iskemik inmeli hastalarda kontrol grubuna göre anlamlı düzeyde daha yüksek bulundu $(0.471 \pm 0.072$ and $0.423 \pm 0.048, \mathrm{p}<0.05)$. PON1 aktivitesi, iskemik inmeli hastalarda kontrol grubuna göre anlamlı düzeyde daha düşük bulundu (417.76 \pm 79.72 and $432.34 \pm 92.05$ p<0.05). PPI ile PON1 ve LVEF arasında negatif zayıf korelasyon saptadık (p<0.05). Ayrıca PON1, PPI'nin bağımsız bir ön belirleyicisidir.

Sonuç: Bu çalışmada, akut iskemik inmeli hastalarda kontrol grubuna göre, PON1 aktivitesi daha düşük, PPI ise daha yüksek bulundu. Bulgularımız, akut iskemik inmeli hastalarda PON1 aktivitesinin, PPI'nin bağımsız bir ön belirleyicisi olduğunu ileri sürmektedir.

Anahtar kelimeler: Paraoksonaz, nabız basıncı, inme.

\section{INTRODUCTION}

Stroke is a multifactorial disease arising from environmental and genetic risk factors or their interaction ${ }^{1}$. The pathogenesis of acute cerebrovascular diseases is carotid atherosclerosis ${ }^{2}$. Free radical activity and hypertension were associated with atherosclerotic cerebrovascular and cardiovascular diseases. Oxidized low density lipoproteins (LDL) in the vascular wall is a significant pathophysiology of cerebrovascular atherosclerosis. Paraoxonase-1 (PON1) has got antioxidant property ${ }^{3}$. This enzyme prevents oxidation of blood lipids 4 . Therefore, PON1 can decrease progression of atherosclerotic disease. Also, PON1 activity can influence atherosclerotic cerebrovascular disease. Increased vascular free radical activity is an important pathophysiology of arterial hypertension ${ }^{5}$. In arterial hypertension, reactive oxygen radicals (ROR) can influence the antioxidant activity of enzymes. The significance of ROR in vascular endothelial function and the pathogenesis of arterial hypertension have been lately investigated ${ }^{6}$.

Elevated pulse pressure (PP) is a major clinical risk factor for coroner and cerebrovascular morbidity and mortality 7 . Cardiovascular factors are affecting PP. Prior clinical trial findings on PP demonstrated that: (1) PP is a major risk factor for $\mathrm{CV}$ disease, and mortality, (2) genes may affect PP and (3) gender may affect PP, CV disease and mortality ${ }^{8}$. Nevertheless, there are drawbacks for PP as an assessment for index. In order to overcome the drawback of PP, there is a novel parameter, "pulse pressure/systolic pressure" termed "pulse pressure index (PPI)" for evaluation of cardiovascular consequences ${ }^{9}$. We investigated the association between Paraoxonase-1 (PON1) activities and pulse pressure index (PPI) in acute ischemic stroke patients.

\section{METHODS}

\section{Patient selection}

This cross-sectional study included 46 adult patients (Females, 27; males, 19; mean age, $68 \pm$ 
13 years; range 41-86 years) with acute ischemic stroke ( $\leq 24$ hours of symptom onset) admitted to the neurology care unit, between November 2013 and December 2014 and 32 control patients. They were classified into 2 groups: Ischemic stroke patients (Group 1, $n=46)$, control patients (Group 2, $n=32$ ). Demographic, clinical characteristics, laboratory parameters of patients, including stroke severity assessment with NIHSS on admission to the neurology care unit were recorded. Patient clinical data, history of cardiovascular risk factors, and stroke onset were determined, and neurologic examination was conducted at the time of admission. The diagnosis of acute ischemic stroke was made on the basis of neurologic examination and cranial imaging within 24 hours of symptom onset. Patients with a well-defined time of acute ischemic stroke symptom onset were included in this study. Patients who have any prior history of transient ischemic attack or cerebrovascular disease, intracranial hemorrhage were excluded. Exclusion criteria from the study are diseases that affect PON1 activities. These diseases are chronic heart disease, diabetes mellitus, chronic renal disorder and malignancy. Admission stroke severity was determined using the NIHSS score ${ }^{10}$.

All patients were taken immediate cranial computed tomography after admission to emergency care unit. Troponin values were calculated, and the electrocardiogram (ECG) was taken after admission to the neurology care unit. Echocardiographic examination was performed within the first 48 hours of admission to the neurology clinic. The NIHSS evaluation and echocardiographic examination were conducted by blinding investigators (U.O and 0.0, respectively). The study was accepted by the Ethics Committee of our hospital and informed consent was obtained from all patients. Ethics committee approval was obtained for this protocol 411 on 30 / 10 / 2013.
The study was performed in accordance with the principles of the Declaration of Helsinki.

\section{Blood Sampling}

Venous blood samples were obtained from the patients in admission at the neurology care unit. Blood samples were taken from the antecubital vein into blood tubes. Then blood samples were separated from the cells by centrifugation at $5000 \mathrm{rpm}$ for $5 \mathrm{~min}$. Serum samples were aliquoted and stored at $-70^{\circ} \mathrm{C}$ until analysis. PON1 activities were measured with UV spectrophotometric method by using "Rel Assay Diagnostic" kits.

\section{Blood Pressure Measurements}

Blood pressure calculations were performed in all stroke patients within 10 minutes after admission to the neurology care unit. Blood pressure was calculated with a digital blood pressure measuring device after 5 minutes of rest, as recommended by the 7 th Joint National

Committee on Detection, Evaluation and Treatment of High Blood Pressure ${ }^{11}$. Patients were seated or lying on the bed with their arm bared and supported at heart level. Two readings, separated by 2 minutes, were obtained and averaged. Additional blood pressure measurements were obtained if these measurements differed by $>5 \mathrm{~mm} \mathrm{Hg}$. Pulse pressure was measured by subtraction of diastolic blood pressure from systolic blood pressure. PPI was calculated by "pulse pressure / systolic pressure".

\section{Statistical Analysis}

Statistical analysis was carried out with the SPSS statistical package (Version 12.0; SPSS Inc., Chicago, IL, USA). All baseline clinical parameters were analyzed. Continuous variables with normal Gaussian distribution (tested with the Kolmogorov-Smirnov test for a distribution normality check) were expressed as means $\pm \mathrm{SD}$, and categorical variables as percentages. Independent Sample T-Test, Chisquare test, Pearson's Correlation test and 
regression analysis were used for comparison of data as appropriate. A p value $<0.05$ was considered statistically significant.

\section{RESULTS}

Clinical characteristics of patients are summarized in Table 1. Age, hypertension, systolic blood pressure (BP), diastolic BP, heart rate, $\mathrm{PP}, \mathrm{PPI}$, diabetes mellitus, dyslipidemia, glucose, creatinine, LDL cholesterol were significantly higher in ischemic stroke patients than control group ( $\mathrm{p}<0.05)$. PON-1 activity and HDL cholesterol were significantly lower in ischemic stroke patients than control group $(\mathrm{p}<$ 0.05).

Table I: Clinical characteristics of patients.

\begin{tabular}{|l|l|l|l|}
\hline Variables & $\begin{array}{l}\text { Group } \\
\text { (Ischemic } \\
\text { Stroke) } \mathrm{n}=46\end{array}$ & $\begin{array}{l}\text { Group } \\
\text { (Control } \\
\text { Group) } \mathrm{n}=32\end{array}$ & $\begin{array}{l}\mathrm{p} \\
\text { Value }\end{array}$ \\
\hline Age (years) & $68.5 \pm 13.4$ & $44.1 \pm 18.6$ & 0.003 \\
\hline Gender (F/M), n & $27 / 19$ & $17 / 15$ & 0.234 \\
\hline Hypertension, $\mathrm{n} \%$ & $29(65 \%)$ & $6(18 \%)$ & 0.005 \\
\hline SBP (mmHg) & $158.4 \pm 17.5$ & $124.3 \pm 13.6$ & 0.037 \\
\hline DBP (mmHg) & $97.1 \pm 10.6$ & $74.2 \pm 9.3$ & 0.032 \\
\hline Heart Rate (bpm) & $117.5 \pm 17.2$ & $83.5 \pm 12.3$ & 0.022 \\
\hline PP, mm-Hg & $60.3 \pm 16.5$ & $44.6 \pm 12.7$ & 0.033 \\
\hline PPI & $0.471 \pm 0.072$ & $0.423 \pm 0.048$ & 0.041 \\
\hline Diabetes Mellitus, $\mathrm{n} \%$ & $14(30 \%)$ & $2(6 \%)$ & 0.007 \\
\hline Smoking, $\%$ \% & $7(16 \%)$ & $3(10 \%)$ & 0.583 \\
\hline Dyslipidemia, $\mathrm{n} \%$ & $11(24 \%)$ & $0(0 \%)$ & 0.004 \\
\hline Glucose (mg/dl) & $165.3 \pm 35.6$ & $103.4 \pm 24.3$ & 0.029 \\
\hline HbA1c & $7.8 \pm 2.1$ & $6.3 \pm 1.5$ & 0.043 \\
\hline Creatinine (mg/dL) & $1.6 \pm 0.5$ & $0.9 \pm 0.3$ & 0.037 \\
\hline PON-1 activity & $417.7 \pm 79.7$ & $432.3 \pm 92.0$ & 0.045 \\
\hline LDL cholesterol & $142.1 \pm 29.5$ & $108.3 \pm 17.2$ & 0.042 \\
\hline HDL cholesterol & $34.5 \pm 8.7$ & $42.6 \pm 9.8$ & 0.045 \\
\hline Fo/dL) & & & \\
\hline
\end{tabular}

F:Female, M:Male, SBP: Systolic Blood Pressure, DBP: Diastolic Blood Pressure, PP: Pulse Pressure, PPI: Pulse Pressure Index, PON1: Paraoxonase 1, LDL: Low Density Lipoprotein, HDL: High Density Lipoprotein.
Systolic blood pressure (BP), diastolic BP, heart rate, PP, PPI were significantly higher in ischemic stroke patients than control group $(\mathrm{p}<$ 0.05).

Glucose, creatinine, LDL cholesterol levels were significantly higher in ischemic stroke patients than control group ( $\mathrm{p}<0.05)$. PON-1 activity and HDL cholesterol were significantly lower in ischemic stroke patients than control group $(\mathrm{p}<$ 0.05).

\section{Echocardiographic Findings}

Echocardiographic findings are summarized in Table 2. LV septal thickness, LV diastolic diameter, LV posterior wall thickness, and E/e' values were significantly higher in Group 1 patients than in Group 2 patients ( $p<0.05$ ). LVEF was significantly lower in Group 1 patients than in Group 2 patients $(\mathrm{p}<0.05)$.

Table II: Echocardiographic parameters of patients.

\begin{tabular}{|l|l|l|l|}
\hline Variables & $\begin{array}{l}\text { Group } \\
\text { (Ischemic } \\
\text { Stroke) } \mathrm{n}=46\end{array}$ & $\begin{array}{l}\text { Group } \\
\text { (Control Group) } \\
\mathrm{n}=32\end{array}$ & p Value \\
\hline $\begin{array}{l}\text { LV septal } \\
\text { thickness, mm }\end{array}$ & $11.8 \pm 1.2$ & $10.6 \pm 0.9$ & 0.029 \\
\hline LVDd (mm) & $53.4 \pm 5.9$ & $48.7 \pm 4.5$ & 0.042 \\
\hline $\begin{array}{l}\text { LV posterior Wall } \\
\text { thickness, mm }\end{array}$ & $11.2 \pm 1.1$ & $10.4 \pm 0.9$ & 0.037 \\
\hline LVDs (mm) & $42.4 \pm 3.9$ & $39.1 \pm 3.7$ & 0.276 \\
\hline LAD (mm) & $41.7 \pm 3.8$ & $38.3 \pm 3.5$ & 0.573 \\
\hline RAD (mm) & $33.7 \pm 3.2$ & $31.5 \pm 2.8$ & 0.563 \\
\hline RVDd (mm) & $29.6 \pm 2.3$ & $28.1 \pm 2.4$ & 0.274 \\
\hline LVEF (\%) & $52.3 \pm 5.8$ & $59.7 \pm 5.2$ & 0.042 \\
\hline E/e' & $10.1 \pm 3.7$ & $7.5 \pm 2.96$ & 0.026 \\
\hline
\end{tabular}

LV: Left Ventricle, LVDd: Left ventricular diastolic diameter, LVDs: Left ventricular systolic diameter, LAD: Left atrial diameter, RAD: Right atrial diameter, RVDd: Right ventricular diastolic diameter, LVEF: Left ventricular ejection fraction.

Correlation analysis was performed to investigate the relationship between PPI and clinical parameters. It showed a weak negative 
correlation between the PPI and LVEF, PON. In addition, there was a positive correlation between the PPI and E/e', age, heart rate, SBP (Table 3). Logistic regression analysis was performed to identify the potential predictors for PPI. Results of the multivariate analysis revealed that age, SBP, LVEF, PON and heart rate were a powerful predictor of PPI. Also, PON is independent predictor of PPI (Table 4).

Table III: Correlation of patients' characteristics and pulse pressure index.

\begin{tabular}{|l|l|l|}
\hline Parameters & $\begin{array}{l}\text { Pearson's correlation } \\
\text { coefficient (r value) }\end{array}$ & $\mathrm{p}$ Value \\
\hline LVEF & -0.427 & 0.042 \\
\hline E/e' & 0.329 & 0.032 \\
\hline PON & -0.413 & 0.041 \\
\hline Age & 0.472 & 0.039 \\
\hline SBP & 0.425 & 0.040 \\
\hline Heart rate & 0.234 & 0.046 \\
\hline \multicolumn{2}{|l|}{} \\
LVEF: Left ventricular ejection fraction, PON: Paraoxonase, SBP: Systolic \\
Blood Pressure.
\end{tabular}

Table IV: Multivariate logistic regression analysis between PPI and clinical parameters.

\begin{tabular}{|l|l|l|l|}
\hline Parameters & OR & $95 \%$ CI & p Value \\
\hline SBP & 0.615 & $0.517-0.792$ & 0.032 \\
\hline LVEF & 0.835 & $0.770-0.920$ & 0.028 \\
\hline PON & 0.469 & $0.314-0.659$ & 0.043 \\
\hline Age & 0.426 & $0.248-0.752$ & 0.040 \\
\hline Heart rate & 0.397 & $0.213-0.654$ & 0.043 \\
\hline
\end{tabular}

SBP: Systolic Blood pressure, PON: Paraoxonase, LVEF: Left ventricular ejection fraction.

\section{DISCUSSION}

Acute stroke is identified as one of the significant reasons of mortality and morbidity ${ }^{12}$. Stroke is a multifactorial disease. This may account why the incidence of acute stroke demonstrates racial and regional variations. There is a proof for ROR relevance in pathogenesis of a lot of diseases, with a specific point on those related to atherosclerosis, such as diabetes, cardiovascular disease, acute stroke, and chronic renal diseases. PON1 is a calcium-dependent glycoprotein. PON1 exerts lactonase and peroxidase activities. These enzymatic activities are important in neurological diseases associated with oxidative stres $^{13}$. Shenhar TS et al found that PON1 activity was inversely correlates with cerebrovascular atherosclerosis ${ }^{14}$. Strokes are associated with changes in serum PON1 activity. The present study is the first study in the literature that evaluates the relationship between PON-1 activity and PPI in acute ischemic stroke patients. The main finding of our study is that PON-1 activity is significantly decreased in acute ischemic stroke patients than in control subjects. Also, Kim NS et al reported that PON1 enzyme activity is substantially reduced in ischemic stroke patients compared to healthy controls ${ }^{1}$. Demirdogen et al. demonstrated that reduced PON1 activities of acute ischemic stroke patients were lower than those of control subjects ${ }^{15}$. Liu et al. coordinated a meta-analysis of PON1 genetic polymorphisms and acute ischemic stroke. The $\mathrm{R}$ allele or RR genotype of PON1 Q192R polymorphism had an increased risk for ischemic stroke in the general population ${ }^{16}$. In the opinion of Wannamethee et al., low HDL-C value is a significant risk factor for the development of stroke ${ }^{17}$. In our study, we found that HDL is significantly lower in acute ischemic stroke patients than in healthy controls. Also, we found that LDL cholesterol was significantly higher in acute ischemic stroke patients than in healthy controls.

Acute stroke is characterized by profound autonomic dysregulation, including alterations in the autonomic reflex pathways, central autonomic neuroanatomical sites and hormonal factors. According to prior investigations on BP changes during the early period of stroke, there is much more higher increasing of SBP than DBP during the acute stroke ${ }^{18}$. Acute stress response to stroke events, increased sympathetic tone, and compensatory response to cerebral ischemia might account these evidences ${ }^{19}$. As a result, an increase of PP could have occurred if 
there was more marked elevation of SBP than DBP during acute ischemic stroke period. In this study, we found that SBP, DBP, heart rate, PP, PPI were significantly higher in acute ischemic stroke patients than in healthy controls. Lee KJ et al suggested that PP when calculated in the early period of acute ischemic stroke has relationships with major cerebrovascular and cardiovascular events and recurrent stroke. Also, they are suggested that PP has an important predictive power than other commonly used BP parameters ${ }^{20}$. For ischemic stroke event, other analysis based on the REGARDS population demonstrated that $P P$ was an independent predictor of stroke event after adjusting for DBP or MAP, but not after adjusting for SBP21. A meta-analysis of 16 cohort clinical studies in Japan suggested that a substantial association between PP and ischemic stroke in men $^{22}$. On the other hand, SBP and DBP were not compared with PP in this meta-analysis. Recently, Chang JJ et al. reported that PP as an independent predictor for in hospital mortality in patients with spontaneous intracerebral hemorrhage ${ }^{23}$.

Hypertension, age, hyperlipidemia and Diabetes Mellitus are major risk factors for atherosclerotic cerebrovascular disease ${ }^{24}$. In our study, hypertension was significantly more common in acute ischemic stroke patients. Age was significantly higher in acute ischemic stroke patients than in healthy controls. Strokerelated sympathetic activation is high in patients with acute ischemic stroke. Irrespective of prior cardiovascular status, an acute phase of stroke markedly influences LV function, and biochemical parameters (Glucose, troponin, creatinine $)^{25}$. In this study, we found that LVEF was significantly lower in acute ischemic stroke patients than in healthy controls. Ozturk $\mathrm{U}$ et al. found that the severe acute ischemic stroke patients had lower LVEF$^{26}$.
Hendrix $\mathrm{P}$ et al. found that diabetes mellitus history is an important predictor of stroke severity ${ }^{27}$. Lindsberg et al. suggested that increased blood glucose is frequent in the acute period of stroke ${ }^{28}$. In our study blood glucose and $\mathrm{HbA1c}$ levels were significantly higher in acute ischemic stroke patients than in healthy controls. Lindsberg PJ et al. reported that diabetes is frequent in severe acute ischemic patients. But, stress related hyperglycemia is more common in these patients ${ }^{28}$. In our study we found that E/é value was significantly higher in severe stroke patients. Ryu WS et al. suggested that E/e' ratios were associated with arterial occlusion in AF-related stroke and may play a role in identifying patients at high risk of severe stroke ${ }^{29}$. In this study we found that creatinine levels were significantly higher in acute ischemic stroke patients. Mostofsky E et al. suggesting that, shared risk factors underlying vascular diseases including age, diabetes mellitus, hypertension, left ventricular hypertrophy may represent a unique vascular pathogenesis resulting from reduced renal clearance. Renal function predicts survival in patients with acute ischemic stroke ${ }^{30}$.

\section{CONCLUSION}

This study demonstrated that PON1 activity is lower and PPI is higher in acute ischemic stroke patients than control subjects. Our results suggested that, PON-1 activity is an independent predictor of pulse pressure index in acute ischemic stroke patients. PON-1 weakly correlates with pulse pressure index.

Ethics Committee Approval: The study was accepted by the Ethics Committee of our hospital and informed consent was obtained from all patients. The study was performed in accordance with the principles of the Declaration of Helsinki. Ethics committee approval was obtained for this protocol 411 on 30 / 12 / 2013. 
Declaration of Conflicting Interests: The authors declare that they have no conflict of interest.

Financial Disclosure: No financial support was received.

\section{REFERENCES}

1. Kim NS, Kang $\mathrm{K}$, Cha $\mathrm{MH}$, et al. Decreased paraoxonase-1 activity is a risk factor for ischemic stroke in Koreans. Biochem Biophys Res Commun. 2007; 364: 157-62.

2. Aydin Ozturk P, Yilmaz T, Ozturk U. Effects of Bemiparin Sodium Versus Dabigatran Etexilate After Anastomosis in Rat Carotid Arteries on the Development of Neointima and Thrombolytic Efficacy. World Neurosurg. 2019; 126: e731-e5.

3. Mackness MI, Arrol S, Durrington PN. Paraoxonase prevents accumulation of lipoperoxides in lowdensity lipoprotein. FEBS Lett. 1991; 286: 152-4.

4. Rozenberg O, Shih DM, Aviram M. Human serum paraoxonase 1 decreases macrophage cholesterol biosynthesis: possible role for its phospholipase-A2like activity and lysophosphatidylcholine formation. Arterioscler Thromb Vasc Biol. 2003; 23: 461-7.

5. Miyajima K, Minatoguchi S, Ito Y, et al. Reduction of QTc dispersion by the angiotensin II receptor blocker valsartan may be related to its anti-oxidative stress effect in patients with essential hypertension. Hypertension Res. 2007; 30: 307-13.

6. Touyz RM, Schiffrin EL. Reactive oxygen species in vascular biology: implications in hypertension. Histochem Cell Biol. 2004; 122: 339-52.

7. Assmann G, Cullen P, Evers T, Petzinna D, Schulte $\mathrm{H}$. Importance of arterial pulse pressure as a predictor of coronary heart disease risk in PROCAM. Eur Heart J. 2005; 26: 2120-6.

8. Lynch AI, Arnett DK, Pankow JS, et al. Sex-specific effects of ACE I/D and AGT-M235T on pulse pressure: the HyperGEN Study. Hum Genet. 2007; 122: 33-40.

9. Cai A, Mo Y, Zhang Y, et al. Relationship of pulse pressure index and carotid intima-media thickness in hypertensive adults. Clin Exp Hypertens. 2015; 37: 267-70.
10. Lyden P. Using the National Institutes of Health Stroke Scale: A Cautionary Tale. Stroke. 2017; 48: 513-9.

11. Chobanian AV, Bakris GL, Black HR, et al. The Seventh Report of the Joint National Committee on Prevention, Detection, Evaluation, and Treatment of High Blood Pressure: the JNC 7 report. Jama. 2003; 289: 2560-72.

12. Feigin VL, Forouzanfar MH, Krishnamurthi R, et al. Global and regional burden of stroke during 1990-2010: findings from the Global Burden of Disease Study 2010. Lancet. 2014; 383: 245-54.

13. Rodriguez-Esparragon F, Lopez-Fernandez JC, Buset-Rios $\mathrm{N}$, et al. Paraoxonase 1 and 2 gene variants and the ischemic stroke risk in Gran Canaria population: an association study and meta-analysis. Int J Neurosci. 2017; 127: 191-8.

14. Shenhar-Tsarfaty S, Waiskopf N, Ofek K, et al. Atherosclerosis and arteriosclerosis parameters in stroke patients associate with paraoxonase polymorphism and esterase activities. Eur J Neurol. 2013; 20: 891-8.

15. Can Demirdöğen B, Türkanoğlu A, Bek S, et al. Paraoxonase/arylesterase ratio, PON1 192Q/R polymorphism and PON1 status are associated with increased risk of ischemic stroke. Clin Biochem. 2008; 41: 1-9.

16. Liu H, Xia P, Liu $M$, et al. PON gene polymorphisms and ischaemic stroke: a systematic review and meta analysis. Int J Stroke. 2013; 8: 11123.

17. Wannamethee SG, Shaper AG, Ebrahim S. HDLCholesterol, total cholesterol, and the risk of stroke in middle-aged British men. Stroke. 2000; 31: 18828.

18. Morfis L, Schwartz RS, Poulos R, Howes LG. Blood pressure changes in acute cerebral infarction and hemorrhage. Stroke. 1997; 28: 1401-5.

19. Castillo J, Leira R, Garcia MM, et al. Blood pressure decrease during the acute phase of ischemic stroke is associated with brain injury and poor stroke outcome. Stroke. 2004; 35: 520-6.

20. Lee KJ, Kim BJ, Han MK, et al. Predictive Value of Pulse Pressure in Acute Ischemic Stroke for Future Major Vascular Events. Stroke. 2018; 49: 46-53. 
21. Glasser SP, Halberg DL, Sands CD, et al. Is Pulse Pressure an Independent Risk Factor for Incident Stroke, REasons for Geographic And Racial Differences in Stroke. Am J Hypertens. 2015; 28: 987-94.

22. Miura K, Nakagawa H, Ohashi Y, et al. Four blood pressure indexes and the risk of stroke and myocardial infarction in Japanese men and women: a meta-analysis of 16 cohort studies. Circulation. 2009; 119: 1892-8.

23. Chang JJ, Khorchid Y, Dillard K, et al. Elevated Pulse Pressure Levels Are Associated With Increased In-Hospital Mortality in Acute Spontaneous Intracerebral Hemorrhage. Am J Hypertens. 2017; 30: 719-27.

24. Wu CY, Wu HM, Lee JD, Weng HH. Stroke risk factors and subtypes in different age groups: a hospital-based study. Neurol India. 2010; 58: 863-8.

25. Ripoll JG, Blackshear JL, Diaz-Gomez JL. Acute Cardiac Complications in Critical Brain Disease. Neurosurg Clin N Am. 2018; 29: 281-97.
26. Ozturk U, Ozturk 0, Tamam Y. Assessment of Myocardial Function by Myocardial Performance Index in Patients with Acute Ischemic Stroke. Dicle Med J 2019; 46: 715-23.

27. Hendrix P, Sofoluke N, Adams MD, et al. Risk Factors for Acute Ischemic Stroke Caused by Anterior Large Vessel Occlusion. Stroke. 2019; 50: 1074-80.

28. Lindsberg PJ, Roine RO. Hyperglycemia in acute stroke. Stroke. 2004; 35: 363-4.

29. Ryu WS, Bae EK, Park SH, et al. Increased Left Ventricular Filling Pressure and Arterial Occlusion in Stroke Related to Atrial Fibrillation. J Stroke Cerebrovasc Dis. 2018; 27: 1275-82.

30. Mostofsky E, Wellenius GA, Noheria A, et al. Renal function predicts survival in patients with acute ischemic stroke. Cerebrovasc Dis. 2009; 28: 88-94. 